\title{
Resistance to antimicorbial agents in Salmonella typhi in Vietnam: clinical response to therapy and molecular mechanisms
}

\author{
John Wain, To S. Diep, Nguyen T. Chinh, Ha Vinh, Sarah Fortune, Nguyen T.T. Hoa, Nicholas J. White,
} Laura J.V. Piddock, Christopher M. Parry, Jeremy F. Farrar

\begin{abstract}
Abstrak
Pada tahun 1989 hanya $1 \%$ isolat S. typhi di Vietnam yang resisten terhadap berbagai antibiotik (multidrug resistant $=M D R$ ) yaitu terhadap ampisilin, kloramfenikol, trimetoprim, tetrasiklin, sulfonamida; namun pada tahun 1993, sudah 85\% isolat S. typhi adalah MDR. Sejak tahun 1992, fluorokuinolon digunakan secara luas, dan dengan cepat pula berkembang galur resisten kuinolon yang dilaporkan dari area Delta Mekong, Vietnam. Pada tahun 1997, isolat resisten terhadap kuinolon telah mencapai 20\%. Pada suatu uji coba klinik yang dilakukan pada 150 penderita demam tifoid tanpa komplikasi dan diterapi dengan ofloksasin $10 \mathrm{mg} / \mathrm{kg} / \mathrm{hari}$ selama $2-3$ hari, berhasil ditemukan $18 \mathrm{~S}$. typhi yang resisten kuinolon (resisten asam nalidiksat, $N A^{\mathrm{R}}$ ). Waktu yang dibutuhkan untuk menurunkan deman rata-rata 156 (30-366) jam bila penderita terinfeksi oleh S. typhi $N A^{\mathrm{R}}$ dan 84 (12-378) jam pada penderita terinfeksi S. typhi sensitif kuinolon $\left(N A^{\mathrm{R}}\right)(p \leq 0,001)$. Enam dari 18 penderita dengan $\mathrm{S}$. typhi $N A^{\mathrm{R}}$ memerlukan terapi tambahan sedangkan hanya satu dari 132 penderita infeksi $\mathrm{S}$. typhi $N A^{\mathrm{R}}$ memerlukan terapi serupa, dan hasil perhitungan resiko relatif $(95 \% C 1) 44(5,6-345)(p \leq$ 0,0001). Perbedaan kemajuan pengobatan secara klinis tersebut sangat penting dibandingkan dengan bila hanya melihat angka KHM (konsentrasi hambat minimal = MIC) saja. Dengan teknik ekstraksi plasmid dan eksperimen transfer gen dapat terlihat bahwa MDR pada S. typhi di Vietnam dibawa oleh suatu plasmid yang mudah ditransfer dan mempunyai molekul yang besar. Pada tahun 1992 , enam jenis plasmid yang berbeda berhasil diekstraksi dari 22 isolat S. typhi. Pada tahun 1996 hanya dua jenis plasmid diternukan dari 19 galur S. typhi. Dengan teknik PCR dan SSCP pada galur resisten kuinolon ditemukan adanya dua mutasi titik (point mutation) baru pada gen gyrA pada 20 S. typhi yang resisten kuinolon. Mutasi pertama terjadi pada nukleotida 97 menyebabkan berubahnya asam amino Asp menjadi Gly (n=17). Mutasi kedua terjadi pada nukleotida 83 yang menyebabkan berubahnya Ser menjadi Phe ( $n=3)$. Timbulnya galur S. typhi MDR selama tahun 90-an di delta Mekong. Vietnam adalah diperantarai oleh plasmi. Namun kewaspadaan harus pula ditujukan pada peningkatan MDR yang disebabkan oleh adanya perubahan kromosomal. Meskipun seringkali sesitivitas in vitro adalah sama, namun terdapat perbedaan yang besar pada hasil pengobatan antara infeksi $N A^{\mathrm{R}}$ dan $N A^{\mathrm{S}}$. Bertahannya galur $M D R$ serta munculnya S. typhi resisten kuinolon mungkin akan menyebabkan patogen yang penting ini di masa mendatang hanya akan dapat diobati dengan antibiotika sefalosporin generasi ketiga yang jauh lebih mahal.
\end{abstract}

\begin{abstract}
In $19891 \%$ of isolates of S. typhi (ST) in Vietnam were multi-drug resistant (MDR) (Amp. Chlor. Trim. Tet. Sulphon.), by 1993 85\% of ST were resistant to these antibiotics. In 1992 fluoroquinolones uses became widespread, and rapidly quinolone resistance was reported from the Mekong Delta of Vietnam. By $199720 \%$ of isolates were resistant. In a clinical trial of 150 patients with uncomplicated typhoid randomised to 2 or 3 days ofloxacin (10mg/ $\mathrm{kg} /$ day), 18 quinolone (nalidixic acid $N A^{\mathrm{R}}$ ) resistant ST were isolated. The median (range) fever clearance time was 156 (30-366) hours in patients infected with $N A^{\mathrm{R}} \mathrm{ST}$ and 84 (12-378) hours in those infected with $\mathrm{Na}^{\mathrm{S}}$ $S T(p \leq 0.001) .6 / 18$ patients with $N A^{\mathrm{R}}$ isolated required retreatment compared with $1 / 132$ patients with $N A^{\mathrm{S}} S T$, relative risk $(95 \% C l)$ 44 (5.6-345) ( $p \leq 0.0001)$. These important clinical differences between the $N A^{\mathrm{R}}$ and $N A^{\mathrm{S}}$ isolated were noted despite similar MIC's. By plasmid extraction and transfer experiments we have demonstrated that MDR in $\mathrm{S}$. typhi in Vietnam is mediated by large molecular weight transferable plasmid. In 1992 there were six distinct plasmid patterns extracted from $22 \mathrm{~S}$. typhi isolates. In 1996 there were only 2 plasmid patterns seen in 19 ST strains. PCR and SSCP of the quinolone resistant determining gyrA gene of S. typhi from $20 \mathrm{NA}{ }^{\mathrm{R}}$ isolates revealed two novel point mutations. The first, at nucleotide 97 caused an amino acid change Asp $\Rightarrow G l y(n=17)$. The second, at nucleotide 83 caused a change Ser $\Rightarrow$ Phe (n=3). There has been a rapid emergence of MDR ST strains during the 1990's in the Mekong delta of Vietnam. This is plasmid mediated. Of increasing concern is the development of chromosomally mediated quinolone resistance. There are important differences in the treatment response between $N A^{\mathrm{R}}$ and $N A^{\mathrm{s}}$ infections, despite similar in vitro sensitivities. The persistence of $M D R$ strains and the emergence of quinolone resistant $\mathrm{S}$. typhi may render this important pathogen treatable only with expensive third generation cephalosporins in the near future.
\end{abstract}

Center for Tropical Diseases and Oxford-Wellcome Trust Clinical Research Unit, Ho Chi Minh City, Vietnam. Dept of Infectious Diseases, School of Medicine of Ho Chi Minh City, Vietnam.

Nuffield Dept of Clinical Medicine. Dept of Infection, University of Bimingham, Birmingham, UK 


\section{INTRODUCTION}

Typhoid is a major cause of morbidity in tropical countries. The development of antibiotic resistance in Salmonella typhi poses the considerable threat of increased mortality and morbidity to many communities of the world. In southern Vietnam multidrug resistance (MDR); resistance to chloramphenicol, ampicillin and co-trimoxazole, in $S$. typhi had become established by late 1992 and early 19931. The fluoroquinole antibiotics have been shown to be superior to the third generation cephalosporins ${ }^{1}$ and effective in short courses ${ }^{2}$. Resistance to these compounds will therefore have serious public health consequences, particularly in endemic areas. We report the nature of plasmids involved with transmission of MDR and the emergence of nalidixic acid resistance in isolates of $S$. typhi in southern Vietnam.

\section{MATERIALS AND METHODS}

Prospective diagnostic and treatment studies in typhoid fever have been in progress at the Centre for Tropical Disease, a 500 bed referral centre for patients with infectious diseases, Ho Chi Minh City, since $1992^{1,2,4,5}$. Adults received either ofloxacin 10 $\mathrm{mg} / \mathrm{kg}$ body weight in two daily divided doses for three days or $15 \mathrm{mg} / \mathrm{kg}$ body weight in two daily divided doses for two days. Children received 15 $\mathrm{mg} / \mathrm{kg}$ body weight in two daily divided doses for either three days or for two days. A clinical failure was defined as failure to attain fever clearance 7 days after the start of treatment, associated with lack of resolution of symptoms and signs, or the development of severe of complicated enteric fever. Repeat blood cultures were performed 48 hours after the last dose of ofloxacin and on day 7 if the patient was still febrile on that day. Patients who failed clinically were retreated with a further course of ofloxacin at the discretion of the attending physician or paediatrician. Each study was approved by the Scientific and Ethical committee of the Centre for Tropical Diseases.

All isolates of $S$. typhi were from blood and were identified by specific antiserum (Wellcome Diagnostics, UK) and with standard biochemical tests. Antibiotic disc susceptibility was determined at the time of isolation by the modified Kirby-Bauer method with discs containing ampicillin $(10 \mu \mathrm{g})$, chloramphenicol $(30 \mu \mathrm{g})$, trimethoprim-sulphamethoxazole $(1.25 / 23.75 \mu \mathrm{g})$, ceftriaxone $(30 \mu \mathrm{g})$ and ofloxacin $(5 \mu \mathrm{g})$. Twenty NAR and $3 \mathrm{NA}^{\mathrm{S}}$ isolates of $S$. typhi were studied. DNA prepared from bacterial strains ${ }^{6}$ was amplified by PCR using the oligonucleotide primers P1 (3'-TGTCCGAGATGGCCTGAAGC-5') and biotinylated P2BIO (5'-TACCGTCATAGTTATCCACG-3'). The amplified products were stored at $4^{\circ} \mathrm{C}$ until used for SSCP or DNA sequencing. SSCP was performed using MDE high resolution gel according to the manufacturers instructions (FMC, Rockland, USA) PCR products were purified by binding to streptavidin coated magnetic beads (Dynal, Oslo, Norway) for direct sequencing. Plasmid DNA was extracted by the method of Kado and Lieu.

The clinical features and response to treatment of patients with $\mathrm{NA}^{S}$ and $\mathrm{NA}^{\mathrm{R}}$ isolates and laboratory features of the isolates were compared by Student's $t$ test or analysis of variance. The Mann Whitney U test was used for non normally distributed data. Proportions were compared by survival analysis using the Kaplan-Meier plot and logrank test and relative risk (RR) calculated. The statistical package SPSS for Windows (V6.1.1) was used for these analyses.

\section{RESULTS AND DISCUSSION}

During the treatment trials there were 13 clinical failures, 9 amongst the 18 patients with NAR isolates, i.e. an overall failure rate in these patients of $50 \%$, and $3.1 \%(4 / 132)$ in the patients with NAs strain; RR $(95 \% \mathrm{CI}) 16.5$ (5.7 to 48.1$)(P<0.0001)$. Only one of the clinical failures was also a microbiological failure and this was in the NAR group. Retreatment of these clinical failures with a further course of ofloxacin was considered necessary by the attending physician in one $(0.8 \%)$ of the 132 patients with an NAS isolate and $6(33.3 \%)$ of the 18 patients with a NAR isolate, RR (95\% CI) 44 (5.6 to 345), $(P<0.0001)$. All S. typhi isolates, tested at the time of isolation by disc diffusion, were found to be susceptible to ofloxacin. Of the 41 isolates of $S$. typhi isolated in the first study between December 1992 and June 19932, 26 (63\%) were multidrug resistnt (MDR) but none were nalidixic acid resistant. In the short course treatment studies between October 1993 and December 1994 5,16 there were $150 \mathrm{~S}$. typhi isolates including 117 (78\%) MDR strains of which $18(15 \%)$ were also nalidixic acid resistant. The first $\mathrm{NA}^{\mathrm{R}}$ isolate was detected in October 1993. During 1995 there were 4,946 patients investigated by blood culture on admission to The CTD. S. typhi was isolated from 720 $(14.5 \%)$ cultures of which $662(92 \%)$ were MDR, and $14(2.1 \%)$ of these were also NAR. The MIC values of ofloxacin for the NAR isolates were generally two or three doubling dilution's higher than the NAS isolates although there is some overlap between the 
two groups. Of 51 isolates with an ofloxacin zone $\leq$ $26 \mathrm{~mm} 14$ (27\%) were nalidixic acid-resistant whereas none of 343 isolates with a ofloxacin zone $>26$ $\mathrm{mm}$ were nalidixic acid resistant. Isolates from Vietnam sensitive to nalidixic acid gave the same SSCP pattern as the control $S$. typh $i$ Type A. None of the 20 nalidixic acid resistant isolates had the same pattern as the sensitive strains. There were two novel patterns, designated II $(n=17)$ and III $(n=3)$. The 218 nucleotide fragment of gyrA of the type A control strain of $S$. typhi gave the same sequence for this region of the QRDR of gyrA as the nalidixic acid sensitive strain of S.typhi from Vietnam TY84. Two isolates that gave SSCP pattern II (TY66 and CT48) and two isolates that gave pattern III (5182 and 5214) were chosen for DNA sequencing. Pattern II isolates had a point mutation at codon 83 (C to $\mathrm{T}$ ), substituting phenylalanine for serine.

\section{Acknowledgements}

We would like to thank the Director of the Centre for Tropical Diseases, Cho Quan Hospital, Dr. Viet and the clinical and laboratory staff who were directly involved in this study; Dr. Tran Tinh Hien, Dr. Nguyen Minh Dung and Dr. Delia Bethell. Ofloxacin was kindly provided by Professor A Bryskier of Roussel-UCLAF Pharmaceuticals, Paris. This work was funded by the Wellcome Trust of Great Britain.

\section{REFERENCES}

1. Hein TT, Duong NM, Ha HD, Hoa NT, Diep TS, Phi LT, Arnold $\mathrm{K}$. A randomised comparative study of fleroxacin and ceftriaxone in enteric fever. Trans $\mathrm{R}$ Soc Trop Med Hyg 1994; 88: 464-5.

2. Hien TT, Bethell DB, Hoa NT, Wain J et al. Short course of ofloxacin for treatment of multi drug resistant typhoid. Clin Infect Dis 1995; 20: 917-23.

3. Piddock LJV. Mechänisms of resistance to fluoroquinolones State of the art 1992-1994. Drugs 1995; 49: 29-35.

4. Duong NM, Chau NVV, Anh DCV et al. Short course ofloxacin in the treatment of typhoid fever. JAMA (Southeast Asia) 1995; 11: 21-5.

5. Vinh H, Wain J, Hanh VTN et al. Two or three days of ofloxacin treatment for uncomplicated multi-drug resistant typhoid fever in children. Antimirobs Agents Chemother 1996; 40: 958-61.

6. Ausubel FM, Brent R, Kingstone RE et al. Current Protocols in Molecular Biology, New York: John Wiley and Sons; 1996. 